\title{
Monetary Policy and Its Implications for Balance of Payments Stability in Nigeria: 1980-2010
}

\author{
Anthony Ilegbinosa Imoisi ${ }^{1}$, Lekan Moses Olatunji ${ }^{2} \&$ Bosco Itoro Ekpenyong ${ }^{2}$ \\ ${ }^{1}$ College of Social \& Management Sciences, McPherson University, Ogun State, Nigeria \\ ${ }^{2}$ School of Graduate Studies, Faculty of Social Sciences, Department of Economics, University of Port Harcourt, \\ Rivers State, Nigeria \\ Correspondence: Anthony Ilegbinosa Imoisi, College of Social \& Management Sciences, McPherson University, \\ Seriki Sotayo, Km 96, Lagos-Ibadan Expressway, P.M.B. 2094, Abeokuta, Ogun State, Nigeria. Tel: \\ 80-34-525-743. E-mail: mcanthonyby@yahoo.co.uk
}

Received: November 27, 2012

doi:10.5539/ijef.v5n3p196
Accepted: January 22, 2013 Online Published: February 22, 2013

URL: http://dx.doi.org/10.5539/ijef.v5n3p196

\begin{abstract}
This study examines the efficacy of monetary policy in achieving Balance of Payments stability in Nigeria. One of the stabilization policies with which the government of Nigeria manages the economy is that of Monetary Policy. Monetary Policy formulation in Nigeria is usually targeted at achieving some macro-economic objectives amongst which is equilibrium in the country's Balance of Payments (BOP). The general objective of this research was to examine the relationship between the Balance of Payments position in Nigeria and monetary policy adopted in the country. The research was conducted using an Ordinary Least Squares (OLS) technique of multiple regression models using statistical time series data from 1980-2010. The estimated result shows a positive relationship between the dependent variable (Balance of Payments) and the Independent variables (Money Supply, Exchange Rate and Interest Rate). Specifically, Money Supply and Interest Rate had significant relationship with Balance of Payments, whereas Exchange Rate was not statistically significant. Based on the results, it was therefore recommended that the government should promote the exportation of Nigerian products especially the Non oil products, as this will bring in more foreign exchange into the country, boost productive activities and improve the balance of payments position of the country. Also, the Central Bank of Nigeria should ensure that the monetary policies adopted in the country are complemented with effective fiscal policies to foster economic growth and development in the Nigerian economy.
\end{abstract}

Keywords: balance of payments, monetary policy, fiscal policy, exchange rate, interest rate, money supply

\section{Introduction}

Monetary Policy is a key component of any pro-growth economic system and much so in developing economies such as the Nigerian Economy (Taylor: 2004). In general terms, monetary policy refers to a combination of measures designed to regulate the value, supply and cost of money in an economy in consonance with the expected level of economic activity (Nnanna; 2001). For most economies, Nigerian economy inclusive, the objectives of monetary policy includes price stability, maintenance of Balance of Payments equilibrium, promotion of employment and output growth. Gbosi (2002), posits that monetary policy aims at controlling money supply so as to counteract all undesirable trends in the economy, these undesirable trends may include; unemployment, inflation, sluggish economic growth or disequilibrium in the Balance of Payments. Monetary policy may either be expansionary or restrictive. An expansionary monetary policy is designed to stimulate the growth of aggregate demand through increase in the rate of money supply thereby making credit more available and interest rates lower. An expansionary monetary policy is more appropriate when aggregate demand is low in relation to the capacity of the economy to produce goods and services. On the contrary, if the quantity of money is reduced or restricted, money income will rise slowly so that consumers spend less and funds for investment are difficult to acquire thereby decreasing aggregate investment (restrictive monetary policy).

Thus, to regulate monetary policy in the Nigerian economy, the Central Bank of Nigeria (CBN) employs various instruments which include; Open Market Operation (OMO), Reserve Requirement (RR) and Discount Rate (DR), CBN (1994). The success of monetary policy depends on the operating economic environment, institutional framework adopted, and the choice and mix of the instrument used. However, the current monetary policy 
framework focuses on the maintenance of price stability and Balance of Payments equilibrium, while the promotion of economic growth and employment generation are secondary goals of the policy. Owing to the nature of Nigeria's export and import, there existed a persistent Balance of Payments deficit in the economy. Invariably, Nigeria has paid more to foreign countries than she receives. Thus, the attendant result affects the economy, leading to gross depletion of Nigeria's Foreign Reserves. It has also attracted reduction in the country's productive capacities and persistent inflationary pressures.

Sequel to the above, articulated efforts have been made by monetary authorities especially, Central Bank of Nigeria (CBN), on how to drastically reduce the Balance of Payment s deficits in the economy. This is usually done through the formulation and implementation of appropriate monetary policy measures. The objective of this study is to; identify the extent to which monetary policy has achieved Balance of Payment stability in Nigeria. Identify the causes and effects of Balance of Payments deficits in the Nigeria economy from 1980-2010. However, our basic focus here is to identify and define the extent to which monetary policy measures have achieved Balance of Payments stability in Nigeria? Providing answers to justify this question is the basic thrust and focus of the study.

\section{Literature Review}

A thought-provoking issue, which has occupied the mind of economists and monetary authorities for decade is the effectiveness of monetary policy in achieving macro-economic objectives. Notwithstanding however, there is the lack of consensus among economists on how it actually works and/or the magnitude of its effect on the economy. Nkoro (2003) observes that there exists a remarkable and strong agreement that monetary policy has some measure of effects on the economy. The Nigerian economy, as in other economies has an apex bank; Central bank of Nigeria (CBN), which has the authority and mandate of manipulating or regulatory monetary policy, using monetary instruments with the aim of achieving desired macro-economic objectives. In Nigeria, these broad objectives include the mandate to conduct and regulate monetary and financial policies with a view o promoting economic growth and development in Nigeria, (Nkoro, 2003).

However, the primary objective of monetary policy in any modern economy is the maintenance of price stability which is fundamental to the attainment of sustainable growth. Nnanna (2001) observed that the pursuit of price stability invariably implies the indirect pursuit of objectives such as Balance of Payments (BOP) equilibrium. Anyanwu (1993) posits that an excess supply of money in the economy will result to excess demand for goods and services and in turn causes rise in prices and also, affect the Balance of Payments position. With the achievement of price stability, the uncertainties of general price level will not materially affect consumption and investment decisions. Rather, economic agents will take long-term decision without much reservation about price change in the macro-economy. The condition in the financial markets and institutions would create a high degree of confidence, such that the financial infrastructure of the economy is able to meet the requirements of market participants (Nkoro 2003). In other words, an unstable and crisis-ridden financial system will render the transmission mechanism of monetary policy less effective, making the achievement and maintenance of strong macroeconomic fundamentals difficult.

\subsection{Instruments of Monetary Policy}

In its effort to achieve a stable macroeconomic policy, the Central Bank of Nigeria adopts and employs monetary policy instruments. As identified by Iyoha (2002), the instrument of discretional monetary policy includes:

Open Market Operation: - This involves the sales or purchase of government securities (Treasury bills) to and from deposit money banks and non-banking institutions with the view to regulate the costs and availability of credit.

Discount Rate: - This is the rate at which the Central Bank of Nigeria lends to deposit money banks. The interest rate charged by the Central Bank of Nigeria is known as discount rate. By varying discount rate, the CBN can influence credit availability as lender of last resort to the deposit money banks. Its direct impact is on credit cost that has direct impacts on banks.

Reserve Requirement: - The reserve requirement sets minimum balance on the liquidity of deposit money banks, viz-a-viz their balances. It has two uses, to ensure the solvency of the banking system and control the expansion of credit creation as an objective of monetary policy.

Moral Suasion - This is a process by which the Central Bank of Nigeria makes known to the deposit money banks officials through informal (oral or written) discussions on the direction in which they wish monetary policy to proceed and the contribution which is expected of the deposit money banks. 
Direct Control of Banking System: - It involves the imposition of quantitative ceiling on the overall and /or selective distribution of credit by the Central Bank of Nigeria. The tools are selective, not general, it is also direct.

Direct Regulation of Interest Rate: - This is generally used in Less Developing Countries (LDCs) and not in More Developed Countries (MDCs). In MDCs, interest rate is determined by market forces to a large extent. However, in LDCs, interest rate is regulated or administered. In particular, interest rate is forced within, which both the deposits and the lending rates are expected to be maintained by the deposit money banks.

\subsection{Conceptual Framework on Balance of Payments}

The balance of payments is defined as a systematic record of economic and financial transactions for a given period of time, say one year, between residents of an economy and non residents - rest of the world. These transactions involves the provision and receipts of real resources - goods, services and income - and changes in claims on and liabilities to the rest of the world. Specifically, the balance of payments records transaction in goods, services and income, changes in ownership and other changes in an economy's holdings of monetary gold, Special Drawing Rights (SDRs) and claims on and liabilities to the rest of the world. It also records unrequited or unilateral transfers - the provision or receipts of an economic value without the acceptance or relinquishing of something of equal value. Generally, transactions involving payments to a country by non-resident are classified as credit entries. Those involving payments by country to non-residents are debt entries.

Basically, the balance of payments is divided into the current and capital account. The capital account is made up of portfolio and direct investment, either long or short term capital and capital transfers. While the current account records all current transactions, which are transactions that include either the export or import of goods and services. They include merchandise and services. The capital account also refers to charges in financial assets and liabilities, portfolio investment, external loan drawings and amortization and charges in short-term capital movements. However, it should be noted that development in the other sectors - real, monetary and public - has implications for the balance of payments. As a result, current account deficit may not necessarily be an inappropriate policy to pursue especially in a country that is for example, importing to increase domestic investment. However, in a short-term, import bills may remain unpaid or external reserves could be drawn down. A long-term and more viable solution lies in ensuring balance of payments viability. A viable balance of payments position may be defined as a current account position, which can be financed on a sustainable basis by net capital movements on terms that are compatible with reasonable development, growth prospects and debt servicing capacity as well as macro-economic stability. It can be seen that the balance of payments is linked with the other accounts in a general equilibrium framework. This implies that disequilibrium in one sector; say external sector is transmitted to the other sectors and vice versa. Thus, there is need to achieve both internal and external balance.

According to Marsha (1994), two types of policy measures are used in dealing with balance of payments problems. These are expenditure switching measures and expenditure reducing policies. Expenditure reducing policies refer to fiscal policy (conducted by changing government expenditure and /or taxes) and monetary policy which refers to changes in money supply, which in turn affect interest rate. Expenditure switching policies refers to devaluation (depreciation) and revaluation (appreciation) of the country's currency. The aim of expenditure reducing policies is to reduce domestic expenditure on consumption and increase expenditure on investment, thus, releasing goods and services for exports while leaving aggregate output unchanged. The aim of expenditure switching policies is to switch domestic demand from imported goods to home made goods. However, the extent to which expenditure switching policies is achieved depends on elasticity of supply and demand for tradable goods. If the depreciation of the nominal exchange rate is matched by increase in wages, absorption and inflation, the real exchange rate would not depreciate and so the balance of payments would not improve. However, expenditure reducing policies have costs in terms of loss of output, investment and employment. The loss will be minimized if resources can be easily moved to the tradable goods sector. Alternatively bridging external loans may be contributed to sustain investment and output.

\subsection{Trends in Nigeria's Balance of Payments}

From available data gathered, it showed that in the first half of 1994, there persisted a pressure on the balance of payments position in the country. An overall deficit amounting to N42, 623.3 million was recorded in the balance of payments compared with the surplus of N13, 615.9 million in the corresponding period of 1993. This deficit was noticeable due to the huge current account deficit which substantially outweighed the surplus recorded in the capital account. The deficit was financed through a reschedule of debt service responsibility estimated at N24, 906.4 million (\$1, 138.0 million) during this period. As a result of this development, the 
external debt reduced from $\mathrm{N} 29,093.0$ million ( $\$ 1,329.3$ million) at the end of 1993 to $\mathrm{N} 26,722.8$ million ( $\$ 1$, 222.0 million) at the end of 1994, (CBN, 2010). Nigeria's overall balance of payments however, recorded a surplus of N19, 531.3 million during the first half of 1995.

The balance of payments position of the country however plunged back into a deficit in 1996, 1998 and 1999. This continued decline in the country's balance of payments was assigned to the engorged deficits in the current account which offset the surplus recorded in the capital account. As in the previous years, the financing of the deficit was largely through further accrual of external debt responsibility which fell and amounted to N89, 813 million. Due to this deficit, the main external sector policy adopted in the year 2000 was to build the country's external reserves. The intended purpose was to restore confidence in the Nigerian Naira $(\mathrm{N})$ and in the entire economy. This effect of this external sector policy was reflected in the balance of payments position of the country. As a result of this policy, the country recorded a surplus in the balance of payments position i.e. Nigeria recorded a surplus of N314, 139.2 million in 2000, and N24, 738.7 million in 2001.

The weak position in the country's current account was due to the deterioration in the services and income account which outweighed the surplus recorded in the merchandise trade and involved net transfer account, (Gbosi, 2001).In recent years, there have persistent deficit in the country's balance of payments (See table 1). Nigeria's balance of payments recorded remarkable improvement during the period 2004-2005. However, the situation worsened in 2008 as a result of the global financial and econosmic meltdown coupled with the falling prices of crude oil in the international oil market (Gbosi, 2009).

\subsection{Balance of Payments Theories}

There are two basic theories that have been propounded to addressing balance of payments imbalance, these include:

Inflationary theory: Inflation is a state of persistent rise in the general price level and hence falling value of money, Dullo (1974). It is a malign condition that eats accumulated wealth and diverts the energies of the economy. Countries report by the IMF, shows that the cause of Nigeria's inflation are; increase in money supply despite decrease in foreign exchange reserves (a decrease in foreign exchange reserve has the effect of decreasing money supply). Budget deficit is also stated to be a contributory factor. Faced with increasing population and the need to improve the standard of living, the Nigerian government has embarked on various programmes to accelerate the rate of economic growth and provide government services, thereby increasing expenditure within a limited scope of public borrowing leading to fiscal deficits.

Structural Theory: This theory argues that balance of payments disequilibrium abates due to an inherently inefficient or imbalanced economy Gbosi (2001). Two specifications of structural problems that affect the Nigerian economy are:

Weakness in fiscal system: This leads to budget deficit, expenditure increases due to population increase and the need for development, while the revenue system and tax rate of the Nigerian economy are inadequate to obtain the needed growth in revenue. What is needed is restructuring and improvement of the country's revenue system and increase in taxes. The revenue system of the economy should be elastic relative to economic growth, that is, revenue should grow proportionally with higher GNP.

High External Debt Burden: Debt sustainability analysis of Nigeria by the IMF indicates that the country's debt has been increasing since1960. Over a period of 30 years, the external debt has risen by 2,899 percent. Determining whether or not the level of debt is sustainable in the country is one of the most fundamental issues. There is no conclusive level of measure amongst economists to determine when an external debt is sustainable or not. However, for debt to be sustainable over the long term, a country's rate of economic growth should be higher than the rate of interest on foreign loans.

Structural inadequacies of Nigeria arose mainly from the flowing sources: Dependence on one primary commodity (especially petroleum) as a major source of foreign exchange earner. This commodity is open to world price fluctuations which affects the current account of the balance of payments; Excessive debt service payment due to high non-concessional interest rates; and Weak industrial base by the manufacturing sector of the country.

\section{Method of the Study}

Here, the research methodology used for the study will be discussed. Emphases were laid on the sources of data, model specification, apriori expectation of variables, etc. 


\subsection{Sources of Data}

The data used for this study is mainly secondary data. Some of these data sources include the publications of Central Bank of Nigeria (CBN), National Bureau of Statistics (NBS), published and unpublished sources, magazines, journals, text books and News papers.

\subsection{Model Specification}

The model was analyzed using an econometric model of multiple regression analysis to test the relationship between the dependent variable (BOP) and independent variables (Money Supply, Interest Rate and Exchange Rate). The model is specified as thus:

$$
B O P=f(M S, I R, E X R)
$$

We can also specify the above equation in an econometric form

$$
B O P_{t}=a_{0}+a_{1} M S_{t}+a_{2} I R_{t}+a_{3} E X R_{t}+U_{t}
$$

While the log-linear function of the model is specified as thus:

$$
\log B O P_{t}=\log a_{0}+a_{1} \log M S_{t}+a_{2} \log I R_{t}+a_{3} \log E X R_{t}+U_{t}
$$

Where:

$$
\begin{aligned}
& \mathrm{BOP}_{\mathrm{t}}=\text { Balance of Payments (BOP) at time ' } \mathrm{t} \text { ' } \\
& \mathrm{MS}_{\mathrm{t}}=\text { Money Supply (MS) at time' } \mathrm{t} \text { ' } \\
& \mathrm{IR}_{\mathrm{t}}=\text { Interest Rate (IR) at time ' } \mathrm{t} \text { ' } \\
& \mathrm{EXR}_{\mathrm{t}}=\text { Exchange Rate (EXR) at time' } \mathrm{t} \text { ' } \\
& \mathrm{U}_{\mathrm{t}}=\text { Error term at time' } \mathrm{t} \text { ' }
\end{aligned}
$$

\subsection{Apriori Expectation}

Based on economic theory, an increase in money supply will bring about an increase in the total money in circulation in the country. This will therefore increase aggregate demand and lead to a rise in productive activities and investment opportunities in the economy. This rise in the productive activities in the economy will lead to a rise in the export of goods and services, thus, leading to a rise in the balance of payments position of the country. Hence, the coefficient of MS will be positive; i.e. $a_{1}>0$. Also, from economic theory, an increase in the rate of interest will discourage investors from borrowing funds from the financial sector, thus, reducing the level of investment and productive activities in the economy. Such reduction in the productive activities of the country will lead to fall in the balance of payments position in the country. Hence, the coefficient of IR will be negative; $a_{2}<0$. Finally, economic theory tells us that an increase in exchange rate (price of a country's currency with respect to other currencies of the world) will make the domestic currency cheaper in the foreign exchange market. This depreciation in the domestic currency will make our exports cheaper and imports expensive in the international market for goods and services. As a result of this, our goods and services would be more in demand thus, leading to a rise in the balance of payments position of the country. Hence, $a_{3}>0$ 


\section{Data Presentation and Analysis}

Table 1. Data on money supply, interest rate, balance of payments and exchange rate in Nigeria from 1980-2010

\begin{tabular}{|c|c|c|c|c|}
\hline YEAR & Money Supply (MS) M1 & Interest Rate (IR) & Balance of Payments (BOP) & Exchange Rate (EXR) \\
\hline 1980 & 9650.7 & 9.5 & 2402.2 & 0.5464 \\
\hline 1981 & 9915.3 & 10 & -3020.8 & 0.6100 \\
\hline 1982 & 10219.8 & 11.8 & -1398.3 & 0.6729 \\
\hline 1983 & 11517.8 & 11.5 & -301.3 & 0.7241 \\
\hline 1984 & 12497.1 & 13 & 354.9 & 0.7649 \\
\hline 1985 & 13878.0 & 11.8 & 349.1 & 0.8938 \\
\hline 1986 & 13560.4 & 12 & -784.3 & 2.0206 \\
\hline 1987 & 15195.7 & 19.2 & 159.2 & 4.0179 \\
\hline 1988 & 22232.1 & 17.6 & -2294.1 & 4.5367 \\
\hline 1989 & 26268.8 & 24.6 & 8727.8 & 7.3916 \\
\hline 1990 & 39156.2 & 27.7 & 18498.2 & 8.0378 \\
\hline 1991 & 50071.7 & 20.8 & 5959.6 & 9.9095 \\
\hline 1992 & 75970.3 & 31.2 & -65271.8 & 17.2984 \\
\hline 1993 & 118715.4 & 18.3 & 13615.9 & 22.0511 \\
\hline 1994 & 169391.5 & 21 & -42623.3 & 21.8861 \\
\hline 1995 & 201414.5 & 20.8 & 19531.3 & 21.8861 \\
\hline 1996 & 227464.4 & 20.9 & -53152 & 21.8861 \\
\hline 1997 & 268622.9 & 23.3 & 1076.3 & 21.8861 \\
\hline 1998 & 318576.0 & 21.3 & -220675.1 & 21.8860 \\
\hline 1999 & 393078.8 & 27.2 & -326634.3 & 92.5284 \\
\hline 2000 & 637731.1 & 21.6 & 314139.2 & 109.5500 \\
\hline 2001 & 816707.6 & 21.3 & 24738.7 & 112.4864 \\
\hline 2002 & 946253.4 & 29.7 & -567353.3 & 126.4000 \\
\hline 2003 & 1225559.3 & 22.5 & -162839.7 & 135.4067 \\
\hline 2004 & 1330657.8 & 20.7 & 1128379.4 & 132.8417 \\
\hline 2005 & 1725395.8 & 19.5 & 1364845.5 & 130.5550 \\
\hline 2006 & 2280648.9 & 18.70 & 68348.84 & 128.2700 \\
\hline 2007 & 3116272.2 & 18.36 & 62187.02 & 117.9860 \\
\hline 2008 & 4857312.2 & 18.70 & 63648.72 & 130.7500 \\
\hline 2009 & 5003866.6 & 22.90 & 80826.64 & 147.6000 \\
\hline 2010 & 4930589.4 & 19.99 & 68887.46 & 139.1750 \\
\hline
\end{tabular}

Source: CBN, Nigeria Major Economic, Financial and Banking Indicators, 2009.

CBN Statistical Bulletin, 2010.

National Bureau of Statistics 2009.

The table above presents the relationship between money supply, interest rate, exchange rate (Independent Variables) and balance of payments (Dependent Variable) in Nigeria for the period under review i.e. 1980-2010. From Table I, we can see that during the period of 1986-1987, when the country introduced the Structural Adjustment Programme; whose objectives included diversifying the productive base of the economy, adoption of realistic exchange rate through the establishment of Foreign Exchange Market, minimal inflationary growth rate etc, there was an improvement in the position of the country's balance of payments, i.e. the country recorded a surplus in her balance of payments position. As depicted from the table, during the 1986-87, as the exchange rate of the Nigerian naira to the United States Dollars depreciated from N2.02 - \$1 to N4.02 - \$1, the balance of payments position moved from a deficit of 748.3 to a surplus of 159.2. This depreciation of the Nigerian naira will now make the exports of Nigerian products cheaper and imports of foreign goods into the economy more expensive. Thus, it will improve the nation's balance of payments position. Also, from the table, from 1994-1995, due to financial sector reforms by the Central Bank of Nigeria we noticed an increase in the money supply in the economy i.e. from N169,391.5 million to N201,414.5 million. This increase in money supply moved the 
country's balance of payments position from a deficit of 42623.3 to a surplus of 19531.3. This shows that monetary policy such as changes in the money supply can be used to influence the balance of payments position of the country, (Gbosi, 2001).

\subsection{Data Analysis and Interpretation of Result}

$$
\begin{gathered}
\mathrm{BOP}=167714.4+0.9326 \mathrm{MS}-1.1425 \mathrm{IR}+9.6246 \mathrm{EXR} \\
\mathrm{t} \text {-stat } \quad(0.89) \quad(4.21) \quad(-2.81) \quad(-1.13) \\
\mathrm{R}^{2}=0.76 \text {, Adjusted } \mathrm{R}^{2}=0.72, \mathrm{~F}=10.10, \text { Durbin Watson }=1.1364
\end{gathered}
$$

\section{Source: IBM SPSS version 19}

The analysis was estimated both in linear form and log-linear form, the linear estimation gave us a better result and was adopted for our analysis based on the goodness of fit of the regression model. From our result, the coefficient of the Independent variables (Money Supply, Interest Rate and Exchange Rate) appeared with the correct sign, thus, conforming to economic theory or apriori expectation.

The coefficient of autonomous balance of payments is 167714.4, meaning that if all the independent variables are held constant; there will be a positive variation in the balance of payments position in the country to the tune of 167714.4 .

Money Supply appeared with the right sign, which is a positive sign and thus, conform to economic theory. The indication of this is that there is a positive relationship between money supply and balance of payments in Nigeria for the period under review. From our result, we observed that the coefficient of money supply is 0.9326 indicating that a unit increase in money supply, would lead to a 0.9326 increase in balance of payments. The estimated coefficient of interest rate appeared with the right sign which is negative and thus, conforms to economic theory, which states that there is an inverse relationship between balance of payments and interest rate. Our result shows that the coefficient of interest rate is -1.1425 , meaning that a unit increase in interest rate would lead to a 1.1425 decrease in balance of payments.

Similarly, the coefficient of exchange rate appeared with the right sign, which is a positive sign, thus, conforming to apriori expectation. This means that there is a positive relationship between exchange rate and balance of payments in Nigeria for the period under review. Our result showed that the coefficient of exchange rate is 9.6246 , meaning that an increase in exchange rate would lead to a 9.6246 increase in the balance of payments position in the country.

Our result also showed that the coefficient of multiple regression $\left(\mathrm{R}^{2}\right)$ is 0.76 , meaning that $76 \%$ of the dependent variable (balance of payments) is explained by the independent variables (money supply, interest rate and exchange rate), while the other $24 \%$ is explained by factors not included in the model, but are captured by the error term for the period under review (1980-2010). This also indicates that the goodness of fit of the regression result is strong and implies that $76 \%$ variation in balance of payments is explained by money supply, interest rate and exchange rate.

The test of significance from our result showed that only money supply and interest rate were statistically significant for the period under review at $5 \%$ level of significance. This is due to the fact that their calculated $t$ value $\left(t_{\text {cal }}\right)$ in absolute terms is greater than their theoretical value of $t\left(t_{\text {tab }}\right)$. For instance, the $t_{\text {cal }}$ of money supply in absolute terms (4.21) is greater than the $t_{\text {tab }}(1.70)$, implying that there is a significant relationship between money supply and balance of payments. Also, the $t_{c a l}$ of interest rate in absolute terms (2.81) is greater than the $\mathrm{t}_{\mathrm{tab}}(1.70)$, indicating that the relationship between balance of payments and interest rate is statistically significant. However, exchange rate was not statistically significant for the period under review because its calculated $t$ value in absolute term $\left(\mathrm{t}_{\text {cal }}=1.13\right)$ is less than the theoretical value of $\mathrm{t}\left(\mathrm{t}_{\mathrm{tab}}=1.70\right)$.

The $\mathrm{F}$ test, which shows the significance of the entire regression model from our result, was significant. This is due to the fact that the observed F-cal ratio (10.10) is greater than the theoretical value of F (1.88) and this further confirms the value of the $\mathrm{R}^{2}$.

\subsection{Discussion of Findings}

For this study, quantitative tools were employed to verify the impact of monetary policies on balance of payments stability in Nigeria for the period under review (1980-2010). From our result, we discovered the following:

1). Money Supply which is the total money in circulation in the economy contributed significantly to the balance of payments position in the country. This is revealed by the positive value of the coefficient of money supply. Hence, the Central Bank of Nigeria has been relying on policies regarding the manipulation of money supply as 
one of its monetary policies in ensuring stability in the country's balance of payments position. This means that if the total money in circulation (money supply) is increasing in Nigeria, there would be an increase in the balance of payments position in the country for the period under review. When there is an increase in money supply in the country, it would lead to a fall in interest rates; this fall in interest rates will encourage borrowing from the financial institutions for investment purposes. An increase in investment opportunities would lead to an increase the level of productive activities in the country. This rise in productive activities will lead to an increase in exports of goods and services to other countries of the world, thus, increasing the level of foreign exchange earnings into the country and leading to a favourable position in the country's balance of payments.

2). Interest rate which is the cost of borrowing funds from deposit money banks contributed positively to the balance of payments position in the country for the period under review. Regulation of interest rate is also one of the monetary policies used by the Central Bank on Nigeria in achieving balance of payments stability. If there is a rise in the rate of interest in the Nigerian economy, this will discourage borrowing from deposit money banks for investment purposes in the country. However, reverse would be the case if there is a fall in interest rate. This fall in interest rate in the country will increase the level of borrowing from the deposit money banks and will ultimately lead to an increase in the level of investment opportunities in the country. Due to this, there will be an increase in the production of goods and services in the country. As a result of the increase in production of goods and services, the prices of these goods and services will reduce, thus making our exports cheaper and improving the country's balance of payments position.

3). Exchange rate which is the price of the domestic currency (in this case, the naira) in terms of the other currencies of the world had a positive impact on balance of payments but was not significant for the period under review (1980-2010). This means that in order to ensure balance of payments stability in the country, the monetary authorities have been relying more on expenditure reducing polices such as monetary policy than on expenditure switching policies such as devaluation of the country's currency. If the Exchange Rate of the Nigerian Currency (Naira) is increasing in relation to other currencies of the world, the balance of payments position for the Nigerian economy will also be increasing and as such will lead to a favourable position in Nigeria's Balance of Payments. This is possible because as the Exchange Rate of the Nigerian Naira is increasing in relation to other currencies of the world, it would make the country's exports cheaper and imports more expensive, thus switching expenditure from foreign goods to domestic goods.

\section{Conclusion and Recommendations}

This work examines monetary policy and its impact on balance of payments (BOP) stability in Nigeria from 1980 - 2010. Balance of payments position of any country is one of the indicators of economic growth and as such countries try to make sure that they realize favourable balance for payments position. The paper presents monetary policy as a key component of any pro - growth economic strategy. In Nigeria, the design and implementation of monetary policy is the responsibility of the Central Bank of Nigeria (CBN). In line with the above, monetary policy as an intervention strategy by the CBN is aimed primarily at maintenance of price stability and balance of payments (BOP) equilibrium whereas the promotion of economic growth and full employment are secondary. Therefore, it is the responsibility of the government to initiate policies that will guide against political tussles and instability. Based on this, the following recommendations were made: The Central Bank of Nigeria (CBN) should intensify the process of regular monitoring of the operation of deposit money banks to ensure compliance with prudent guidelines and promote transparency in the banking operations; The government should protect infant industries through the following ways: by raising high tariff on those goods that are produced outside the country; encourage import substitution; support local industries and manufacturing sector by giving them incentives such as; Tax holiday etc; the government should embark on efficient and effective expenditure switching policy or devaluation of Nigeria Currency (Naira), as devaluation of the country's currency will make exports cheaper and imports more expensive, thus, leading to a favourable balance of payments position in the country. It should be noted that despite the efforts of the Central Bank of Nigeria in trying to use monetary policy in ensuring balance of payments stability in Nigeria, it has not made the desired impact with regards to the stabilization of the balance of payments position in the country. Also, for monetary policy to be effective in ensuring stability in the balance of payments position of the economy, it should be complemented with an effective fiscal policy.

\section{References}

Ajayi, S. L. (1974). An Econometric Case study of Relative importance of Monetary and Fiscal Policy in Nigeria. Bangladesh Economic Review, 11(2).

Anderson, L. C., \& Jordan, J. L. (1968). Monetary and Fiscal Action A test of their Relative Importance in Economic Stabilization. Federal Reserve Bank of St. Louis Review reprint series no. 34. 
Anyanwu, J. C. (1993). Monetary Economics: Theory, Policy and Institution. Joane Educational Publishing Ltd, Onitsha.

Central Bank of Nigeria. (2010). Statistical Bulletin, 20. Abuja.

Central Bank of Nigeria (2009). Nigeria Major Economic, Financial and Banking Indicators. Abuja.

Fieleke, N. S. (1996). What is Balance of Payments? Federal Reserve Bank of Boston Economic and Financial Review.

Fischer, S. (1994). Modern Central Banking: The Future of Central Bank. The Tercentenary Symposium of the Bank of England: Cambridge University Press.

Folawewo, A. O., \& Osinubi, T. S. (2006). Monetary Policy and Macroeconomic Instability in Nigeria: A Rational Expectation Approach. Kenila Raj.

Gbanador, C. A. (2005). Devaluation and Balance of Payments Stability in an Oil Producing Economy: lessons from Nigeria Experience. The Nigerian Journal of Monetary Economics (NJOME), 5, 118-131

Gbosi, A. N. (2002). Financial Sector Instability and Challenges to Nigeria's Monetary Authorities. African Heritage Publishers, Port Harcourt

Ikhide, S. I., \& Alawode, A. A. (1994). Financial Sector Reforms, Macroeconomics Instability and the order of Economic Research Liberalization; the Evidence from Nigeria. African Economic Research Consortium (AERC) Final report.

Ikhide, S. I. (1996). Financial Sector Reforms and Monetary Policy in Nigeria. IDSS working paper 68.

Iyoha, M. A. (2002). Macroeconomics: Theory and Policy. March Publishers, Benin City.

Iyoha, M. A. (2003). An Overview of leading Issues in the Structure and Development of Nigerian Economy since 1960. In Iyoha, M. A. \& Itsede, C. O. (Eds.), Nigerian Economy: Structure Growth and Development. Mindex Publishing Benin City.

Jhingan, M. L. (1993). Macroeconomic Theory. Delhi: Konar Publishers.

Nkoro, E. (2003). Analysis of the Impact of Monetary policy on Economic Development in Nigeria (1980-2003). University of Benin City.

Nnanna, O. J. (2001). Monetary Management Objectives, Tools and the Role of Central Banks in the Region. Regional Forum on Economic and Financial Managements for Parliamentarian. Nigeria: WAIFEM.

Odozi, V. A. (1995). The Conduct of Monetary and Banking Policies by the Central Bank of Nigeria. Economic and Financial review, 33(1).

Oduma, J. S. (1980). How effective have Fiscal and Monetary Policies been in Nigeria? CSER Print paper no. 7 Abu Zaria

Okaha, G. O. (1986). Theoretical Basis of Monetary Policy in Africa. Economic and Financial review, 10.

Ojo, M. O. (1987). Monetary Policy Instrument in Nigeria: Their Changing Nature and Implication. The Nigerian Bank.

Sanuse, J. O. (2002). The Evolution of Monetary Management in Nigeria and its Impacts on Economic Development. CBN bullion, 26(1).

Soludo, C. (2001). Debt Poverty and Inequalities: Towards an Exit Strategy for Nigeria and Africa. Proceedings from International Conference on Sustainable Debt Strategy. Abuja Nigeria Processed.

Tailor, J. B. (2004). Improvements in Monetary Policy and Implications for Nigeria. Key Note Address, Money Market Association of Nigeria, Abuja, Nigeria.

Uchendu, O. A. (1996). The Transmission of Monetary Policy in Nigeria. Central Bank of Nigeria Economic and Financial Review, 34(2), 608.

Udegbunam, R. I. (2003). Monetary and Financial Policy. In Iyoha, M. A. \& C. O. Itsede (Eds.), Nigerian Economy: Structure Growth and Development. Mindex Publishing Benin City. 